\title{
SHORT-TERM STORABILITY OF OIL SEED AND WALNUT CAKE - MICROBIOLOGICAL ASPECT
}

\author{
J. TARek-TilistyÁK ${ }^{\mathrm{a} *}$, M. JuhÁsz-Román ${ }^{\mathrm{b}}$, J. JeKÖ $^{\mathrm{a}}$ and E. MÁthÉa \\ ${ }^{a}$ Agricultural and Molecular Research Institute, University College of Nyíregyháza, \\ H-4400 Nyíregyháza, Sóstói út 31/b. Hungary \\ ${ }^{\mathrm{b}}$ Department of Microbiology and Biotechnology, Corvinus University of Budapest, \\ H-1118 Budapest, Somlói út 12-16. Hungary
}

(Received: 18 March 2013; accepted: 29 May 2013)

\begin{abstract}
We evaluated the microbiological safety, the short-term storability, and the macronutrients of oil seed cake (OSC) obtained from walnut (WnC), linseed (LC), and sunflower seed with hull (SC). The OSCs had 3.6-5.8\% moisture content, $0.50-0.60$ water activity $\left(\mathrm{a}_{\mathrm{w}}\right), 29.9-39.4 \%$ protein, $15.5-23.6 \%$ fat, and $36.6-48.0 \%$ dietary fibre content. The grinded OSCs could be stored in opaque plastic bags for 4 months at temperatures of $4{ }^{\circ} \mathrm{C}, 14{ }^{\circ} \mathrm{C}$, and $25^{\circ} \mathrm{C}$. Total colony count of mesophilic microorganisms depending on oxygen demand and spore-forming ability, and faecal indicator microorganisms were determined during a 4-month storage term at $4{ }^{\circ} \mathrm{C}, 14{ }^{\circ} \mathrm{C}$, and $25^{\circ} \mathrm{C}$ using traditional culturing methods. The OSCs were free from sulphite-reducing Clostridia and coliforms, including Escherichia coli. Data were analyzed statistically by multifactor analysis of variance. Ascending order of the average contamination of the three products $\left(\log _{10} \mathrm{CFU} \mathrm{g}{ }^{-1}\right)$ was aerobic sporogenic bacteria (2.39), fungal count (2.51), total aerobic microbe count (3.00), anerobic sporogenic bacteria (3.75), and total anaerobic microbe count (4.23). As for the average microbial count, WnC was the least $\left(2.73 \log _{10} \mathrm{CFU} \mathrm{g}{ }^{-1}\right)$ and $\mathrm{LC}$ was the highest $\left(3.53 \log _{10} \mathrm{CFU}\right.$ $\mathrm{g}^{-1}$ ) contaminated material. Regarding the variation of microbial contamination during storage, temperature was indifferent $(\mathrm{P}=0.191)$, while storage time $(\mathrm{P}=0.0033)$ and the product type were influential $(\mathrm{P}=0.000)$.
\end{abstract}

Keywords: walnut, sunflower seed, linseed, pressing residue, cake, microbiology, safety, storage

The interest toward OSCs is still increasing, because they could serve as solutions for nutritional problems like: (i) substitution of protein of animal origin or artificial food additives (Popović, 2010) and (ii) functional fortification of food products.

Considering that OSCs are essentially low-processed and are rich in complex compounds (PerÉdi \& BAlogh, 2005; Mueller et al., 2010), they are riskier materials, hence promoting the growth of contaminant microbiota and the transmission of microbiological and chemical impurities into compounds of foodstuffs through the food chain (MARQUARDT, 1996), as reported for aflatoxins in nuts (Zinedine \& MANes, 2009; Leong et al., 2010), for Enterobacteriaceae (Myint et al., 2007), for Salmonella (Juven et al., 2004), and for fungi (PITT et al., 1993). Heat treatment applied during conditioning, pelleting, or extrusion of oil seeds, has been shown to be an effective way for reducing pathogens and toxin levels (DAVIES $\&$ WRAY, 1997). Improper handling and storage of OSCs can lead to the increase of rancidity, with its attendant unpleasant taste and odour (WALLACE et al., 2010). LC samples with 8-10\% moisture content were chemically stable for 4 months at $20^{\circ} \mathrm{C}$ packed in brown-paper bag (OGunRonbi, 2007). WnC can be stored in plastic bags without chemical degradation below $23{ }^{\circ} \mathrm{C}$ for half a year (VAnhanen \& SAVAGE, 2006). Some papers from developing countries

\footnotetext{
* To whom correspondence should be addressed.

Phone: +36302420247; fax: +3630599478; e-mail: judit.tilistyak@gmail.com
} 
deal with the determination of the microbiological storability of OSCs. After 1 month storage at room temperature the nutritive properties of OSCs significantly decreased and one and a half order of magnitude increase of fungal and bacterial contamination was detected (OladimeJi \& Kolapo, 2008). Duplication of microbial contaminants in parallel with a significant increase of aflatoxin content during 3 months has been observed (KoLAPO et al., 2012). Under farm storage conditions lasting for 5 months, toxigenic isolates of Aspergillus fumigates and Aspergillus repens were found in OSCs producing up to $45 \mu \mathrm{g} \mathrm{kg}^{-1}$ of gliotoxin (LANIER et al. 2009). The composition and the magnitude of microbiological contamination limit the applicability of OSCs in food industry.

In the present work we made controlled storage experiments to study the mesophilic microbiota depending on oxygen demand and spore-forming property, of OSCs obtained from walnut, brown linseed, and sunflower seed with hull during a 4-month storage term at temperatures usually occurring in the industry or housekeeping. Our results indicate that the analyzed OSCs can be safe and microbiologically stable materials.

\section{Materials and methods}

\subsection{Materials}

OSCs obtained from mechanical pressing of walnut, brown linseed, and sunflower seed with hull were studied. Walnut was heated to $60^{\circ} \mathrm{C}$ before pressing. Linseed and sunflower seed was cold pressed, with a $42{ }^{\circ} \mathrm{C}$ outlet temperature. Samples from different pressing batches were produced by Tarpai Manufaktúra Ltd. for WnC and by Solio Ltd. for LC and SC, in 2010. The OSCs were industrially packed in opaque plastic bags of $0.14 \mathrm{~mm}$ thickness, then welded and stored at $4{ }^{\circ} \mathrm{C}$ for further experiments. The culture media were purchased from Merck and VWR International. The chemical reagents were purchased from VWR International.

\subsection{Preparation of OSC and storage parameters}

$10 \mathrm{~kg}$ of each OSCs was grinded in the laboratory using a small capacity feed grinder with a $3 \mathrm{~mm}$ sieve following sterilization with $70 \%$ ethanol. The first $1 \mathrm{~kg}$ of ground OSCs was excluded from the storage experiment. Individual units $(3 \times 1 \mathrm{~kg} \mathrm{OSC})$ were packed in opaque plastic bags with a $300 \mathrm{~mm} \times 500 \mathrm{~mm}$ size and of a $0.14 \mathrm{~mm}$ thickness. The air was removed manually from the bags, then the bags were folded and closed with adhesive tape to avoid oxygenation. The bags were stored at $4{ }^{\circ} \mathrm{C}, 14^{\circ} \mathrm{C}$, and $25^{\circ} \mathrm{C}$ for 4 months.

\subsection{Determination of macronutrient composition}

Macronutrient composition was determined once, at the beginning of the storage. Moisture was determined by air oven method at $103{ }^{\circ} \mathrm{C}$ to constant weight. Protein was calculated as nitrogen content $\times 6.25$, to which nitrogen content was determined by Elementar Rapid $\mathrm{N}$ cube analyzer with the quantitative combustion digestion at $900{ }^{\circ} \mathrm{C}$ in excess oxygen. Total fat content was determined by Soxtec Avanti 2055 Manual System instrument according to the MSZ EN ISO (2000). Ash was determined in electric furnace after 8-h ashing at $550{ }^{\circ} \mathrm{C}$. Total dietary fibre was determined according to the method of Megazyme Total Dietary Fibre Assay Procedure Kit (Noack Group). Water activity, as a 5-min constant value, was measured by Novasina labMaster-a $\mathrm{w}_{\mathrm{w}}$ Basic instrument. 


\subsection{Determination of microbiota}

Traditional culturing methods were applied for microbiological analysis. Samples were taken three times, at the start, the $2^{\text {nd }}$ and the $4^{\text {th }}$ month of the storage term. To prepare the initial suspension of each OSC, we complemented $10 \mathrm{~g} \mathrm{WnC}, 10 \mathrm{~g} \mathrm{SC}$, and $5 \mathrm{~g} \mathrm{LC}$ to $100 \mathrm{ml}$ using sterile pepton water $0.1 \%(\mathrm{w} / \mathrm{v})$. Following thorough shaking and a 30 -minute rehydration at room temperature, 10-fold serial dilutions were prepared. From the dilution tubes, aliquot volume $(0.1 \mathrm{ml})$ was spread onto the surface of culture media in two parallel Petri-dishes. Total mesophilic aerobic microbial count was determined on TPC agar after incubation at $30{ }^{\circ} \mathrm{C}$ for 48 hours. Total count of fungi was determined on $\mathrm{RBC}$ agar incubated at $25^{\circ} \mathrm{C}$ for $5 \mathrm{~d}$. ChromoCULT ${ }^{\circledR}$ Coliform agar was applied for simultaneous detection of colony forming units of total coliforms and Escherichia coli after 24-h incubation at $37{ }^{\circ} \mathrm{C}$. Differential Reinforced Clostridial Media (DRCM) tubes covered with paraffin layer was applied for the determination of the MPN of mesophilic anaerobic bacteria, of spore-forming anaerobic bacteria, and of sulphite-reducing Clostridia. For the determination of these latter ones, 3 parallel tubes were inoculated, then were pasteurized at $80{ }^{\circ} \mathrm{C}$ for $30 \mathrm{~min}$. The inoculated DRCM tubes were incubated at $30{ }^{\circ} \mathrm{C}$ for $44 \mathrm{~h}$. The heat-treated tubes that turned black were considered positive for the determination of sulphite-reducing Clostridia. Total count of aerobic spore-forming bacteria was determined from serial dilution tubes formerly pasteurized at $80{ }^{\circ} \mathrm{C}$ for $30 \mathrm{~min}$, by spread plate method on TPC agar incubated at $37^{\circ} \mathrm{C}$ for $48 \mathrm{~h}$.

\subsection{Statistical analysis}

The measurements were performed in duplicate. Data were analyzed statistically by multifactor analysis of variance with STATGRAPHICS software. The mean values were compared at $95 \%$ level of confidence.

\section{Results and discussion}

\subsection{Macronutrient composition of OSCs}

The results of chemical analysis containing the most important macronutrients are shown in Table 1.

Table 1. Macronutrient composition of OSCs*

\begin{tabular}{lcccccc}
\hline Type of OSC & $\mathrm{a}_{\mathrm{w}}$ & Moisture & Protein & Fat & Ash & TDF \\
\hline Walnut cake & 0.53 & 3.6 & 39.4 & 15.5 & 4.9 & 36.6 \\
Linseed cake & 0.59 & 5.8 & 29.9 & 18.9 & 7.1 & 48.0 \\
Sunflower seed cake (with hull) & 0.55 & 5.0 & 31.9 & 23.6 & 6.4 & 42.0 \\
\hline
\end{tabular}

*: (\%); TDF: total dietary fibre

The studied OSCs were rich in nutrients, as reported in other scientific papers (VANHANEN \& Savage, 2006; Mueller et al., 2010). In contrast with the LC and WnC, the SC with hull did not look suitable for human consumption taking into consideration its appearance (deep grey colour) and hull contained. The $\mathrm{a}_{\mathrm{w}}$ and the moisture content of OSCs were low for storability and suggest compliant cooling process after pressing. 


\subsection{Evaluation of microbiological contamination of OSCS}

Results of the determination of mesophilic microorganisms are summarized in Table 2. OSCs were qualified according to the limits laid down in the Hungarian Agriculture and Rural Development Ministry regulation No 43/2003 (FVM, 2003) (for feed) and Health Ministry regulation No 4/1998 (for food) comparing to brans, due to the lack of official categorization of OSC.

Table 2. Mesophilic microbial contamination* of OSCs during storage

\begin{tabular}{|c|c|c|c|c|c|c|c|c|c|c|c|c|}
\hline \multirow{3}{*}{$\mathrm{a}_{\mathrm{W} * *}$} & \multirow{3}{*}{$\begin{array}{c}\mathrm{T} \\
\left({ }^{\circ} \mathrm{C}\right)\end{array}$} & \multirow{3}{*}{$\begin{array}{c}\mathrm{t} \\
\text { (Month) }\end{array}$} & \multicolumn{6}{|c|}{ Aerobic } & \multicolumn{4}{|c|}{ Anaerobic } \\
\hline & & & \multicolumn{2}{|c|}{$\mathrm{TCC}$} & \multicolumn{2}{|c|}{ TFC } & \multicolumn{2}{|c|}{ TSB } & \multicolumn{2}{|c|}{ TCC } & \multicolumn{2}{|c|}{ TSB } \\
\hline & & & 1 & 2 & 1 & 2 & 1 & 2 & 1 & 2 & 1 & 2 \\
\hline \multicolumn{13}{|c|}{ Walnut cake } \\
\hline \multirow[t]{6}{*}{$0.54 \pm 0.01$} & 4 & 0 & 2.00 & 2.60 & 2.00 & 2.18 & 2.00 & 2.30 & 3.63 & 3.79 & 3.36 & 3.36 \\
\hline & & 2 & 2.70 & 2.18 & 1.70 & 2.00 & 2.15 & 1.70 & 3.88 & 3.37 & 3.43 & 3.37 \\
\hline & & 4 & 2.48 & 2.18 & 1.74 & 2.00 & 2.60 & 2.00 & 3.36 & 3.56 & 3.36 & 3.37 \\
\hline & 14 & 0 & 2.00 & 2.60 & 2.00 & 2.18 & 2.00 & 2.30 & 3.63 & 3.79 & 3.36 & 3.36 \\
\hline & & 2 & 2.51 & 2.18 & 1.70 & 2.18 & 2.18 & 1.70 & 3.88 & 3.82 & 3.56 & 3.63 \\
\hline & & 4 & 2.65 & 2.18 & 2.00 & 1.70 & 2.40 & 2.18 & 3.54 & 3.37 & 3.45 & 3.36 \\
\hline \multirow[t]{3}{*}{$0.50 \pm 0.03$} & 25 & 0 & 2.00 & 2.60 & 2.00 & 2.18 & 2.00 & 2.30 & 3.63 & 3.79 & 3.36 & 3.36 \\
\hline & & 2 & 2.40 & 2.54 & 2.00 & 1.70 & 2.74 & 1.70 & 3.97 & 3.62 & 3.63 & 3.63 \\
\hline & & 4 & 2.90 & 2.74 & 2.48 & 2.00 & 2.18 & 2.48 & 3.63 & 3.63 & 3.36 & 3.32 \\
\hline \multicolumn{13}{|c|}{ Linseed cake } \\
\hline \multirow[t]{6}{*}{$0.60 \pm 0.01$} & 4 & 0 & 3.08 & 3.64 & 2.78 & 3.28 & 2.00 & 3.18 & 4.36 & 4.63 & 3.72 & 4.36 \\
\hline & & 2 & 3.30 & 3.22 & 2.93 & 3.07 & 2.85 & 2.60 & 4.64 & 4.18 & 4.45 & 3.37 \\
\hline & & 4 & 3.34 & 3.43 & 2.90 & 3.13 & 2.70 & 2.18 & 4.36 & 4.37 & 3.97 & 4.37 \\
\hline & 14 & 0 & 3.08 & 3.64 & 2.78 & 3.28 & 2.00 & 3.18 & 4.36 & 4.63 & 3.72 & 4.36 \\
\hline & & 2 & 3.38 & 3.23 & 3.00 & 3.24 & 2.70 & 2.70 & 4.81 & 4.16 & 4.46 & 3.37 \\
\hline & & 4 & 3.48 & 3.41 & 2.90 & 3.08 & 2.81 & 3.10 & 4.59 & 4.63 & 4.18 & 4.35 \\
\hline \multirow[t]{3}{*}{$0.59 \pm 0.01$} & 25 & 0 & 3.08 & 3.64 & 2.78 & 3.28 & 2.00 & 3.18 & 4.36 & 4.63 & 3.72 & 4.36 \\
\hline & & 2 & 3.45 & 3.24 & 3.08 & 3.20 & 2.60 & 2.18 & 4.81 & 4.67 & 4.46 & 3.63 \\
\hline & & 4 & 3.40 & 3.31 & 3.00 & 3.19 & 2.00 & 2.48 & 4.64 & 4.82 & 4.53 & 4.67 \\
\hline
\end{tabular}


Table 2. Cont.

\begin{tabular}{|c|c|c|c|c|c|c|c|c|c|c|c|c|}
\hline \multirow{3}{*}{$\mathrm{a}_{\mathrm{w} * *}$} & \multirow{3}{*}{$\begin{array}{c}\mathrm{T} \\
\left({ }^{\circ} \mathrm{C}\right)\end{array}$} & \multirow{3}{*}{$\begin{array}{c}\mathrm{t} \\
\text { (Month) }\end{array}$} & \multicolumn{6}{|c|}{ Aerobic } & \multicolumn{4}{|c|}{ Anaerobic } \\
\hline & & & \multicolumn{2}{|c|}{ TCC } & \multicolumn{2}{|c|}{ TFC } & \multicolumn{2}{|c|}{ TSB } & \multicolumn{2}{|c|}{ TCC } & \multicolumn{2}{|c|}{ TSB } \\
\hline & & & 1 & 2 & 1 & 2 & 1 & 2 & 1 & 2 & 1 & 2 \\
\hline \multicolumn{13}{|c|}{ Sunflower seed cake (with hull) } \\
\hline \multirow[t]{6}{*}{$0.57 \pm 0.02$} & 4 & 0 & 3.00 & 3.20 & 2.00 & 2.81 & 1.74 & 2.00 & 4.36 & 4.36 & 3.36 & 3.53 \\
\hline & & 2 & 2.90 & 3.68 & 2.26 & 2.40 & 2.40 & 3.27 & 4.46 & 4.63 & 3.36 & 4.22 \\
\hline & & 4 & 3.08 & 3.56 & 2.30 & 2.18 & 2.30 & 2.53 & 4.36 & 4.82 & 3.59 & 4.37 \\
\hline & 14 & 0 & 3.00 & 3.20 & 2.00 & 2.81 & 1.74 & 2.00 & 4.36 & 4.36 & 3.36 & 3.53 \\
\hline & & 2 & 2.98 & 3.28 & 2.00 & 2.74 & 2.60 & 3.16 & 4.41 & 4.37 & 3.98 & 4.18 \\
\hline & & 4 & 3.19 & 3.26 & 2.70 & 2.74 & 2.74 & 2.85 & 4.36 & 4.35 & 3.38 & 4.35 \\
\hline \multirow[t]{3}{*}{$0.53 \pm 0.02$} & 25 & 0 & 3.00 & 3.20 & 2.00 & 2.81 & 1.74 & 2.00 & 4.36 & 4.36 & 3.36 & 3.53 \\
\hline & & 2 & 3.39 & 3.24 & 3.00 & 2.74 & 2.40 & 2.00 & 4.64 & 4.81 & 3.62 & 3.82 \\
\hline & & 4 & 3.45 & 3.36 & 2.88 & 2.65 & 2.85 & 3.34 & 4.63 & 4.67 & 3.56 & 3.63 \\
\hline
\end{tabular}

*: Data are given in $\log _{10} \mathrm{CFU} \mathrm{g}{ }^{-1}$; **: mean value $\pm \mathrm{SD}$ of water activity of OSCs stored at $4{ }^{\circ} \mathrm{C}$ and $25{ }^{\circ} \mathrm{C}$ for 4 months ( $\mathrm{N}=6$ per OSC); TCC: total colony count; TSB: total count of sporogenic bacteria; TFC: total fungal count; italic numbers mean different batches

E. coli and sulphite-reducing Clostridia were not found in any of the samples (data are not shown), due to the careful and hygienic industrial processing. Coliform results predict the likelihood of being free from Salmonella as a prerequisite of nutritional application. The initial mesophilic aerobic microbial contamination of OSCs in the range of 2.00-3.64 $\log _{10} \mathrm{CFU} \mathrm{g} \mathrm{g}^{-1}$ is one-thousandth of the threshold $\left(10^{6} \mathrm{CFU} \mathrm{\textrm {g } ^ { - 1 }}\right)$ laid down for feeds, and $6 \log _{10}$ units lower than the initial microbial contamination of coconut, groundnut, soybean cakes reported by Olajimed and Kolapo (2008). The TFC of LC exceeded the $10^{3}$ CFU g ${ }^{-1}$ threshold laid down for brans. This non-compliance is conditional. In other respects, the studied OSCs could be applied in food industry.

Results of the multifactor analysis of variance are shown in Tables 3 and 4.

Table 3. Multifactor Analysis of Variance for $\log \mathrm{N}$

\begin{tabular}{lrrrrc}
\hline Source of variation & Sum of squares & d.f. & Mean square & $F$-value & Sig. level \\
\hline MAIN EFFECTS & & & & & \\
Temperature & 0.31647 & 2 & 0.15824 & 1.67 & 0.1910 \\
Time & 1.11155 & 2 & 0.55578 & 5.85 & 0.0033 \\
Product & 29.79095 & 2 & 14.89548 & 156.86 & 0.0000 \\
Microbe group & 136.22565 & 4 & 34.05641 & 358.64 & 0.0000 \\
Repetition (batch) & 1.02182 & 1 & 1.02182 & 10.76 & 0.0012 \\
RESIDUAL & 24.49936 & 258 & 0.09496 & & \\
\hline TOTAL & 192.96580 & 269 & & & \\
\hline
\end{tabular}


Depending on the seed variety of OSC, the lowest level of contamination has been detected for $\mathrm{WnC}$, the highest one for $\mathrm{LC}(\mathrm{P}=0.0000)$, which suggests longer storage term for linseed batches applied for LC production and the occurrence of mycotoxins can be assumed. The microbe groups caused significantly different contamination $(\mathrm{P}=0.0000)$. The contaminations from the lowest to the highest were as follows: aerobic sporogenic bacteria, fungi, mesophilic aerobic microbes, anaerobic sporogenic bacteria, and anaerobic bacteria. The majority of the aerobic microbial contamination was fungi for all the OSCs. One and a half order of magnitude more anaerobic sporogenic bacteria were found compared to aerobic ones, which meant the second biggest hazard of the microbe groups studied. This makes the OSCs riskier for food application, e.g. developing processed meat products (e.g. meat batters), the researches of which are in focus (COFRADES et al., 2008).

Table 4. Table of means, confidence intervals and homogeneity

\begin{tabular}{|c|c|c|c|c|}
\hline Level & Count & $\begin{array}{l}95 \text { Percent } \\
\text { Confidence } \\
\text { for mean }\end{array}$ & $\mathrm{LSD}^{\mathrm{a}}$ & Homogeneity $^{\mathrm{b}}$ \\
\hline GRAND MEAN EFFECTS & 270 & $3.174 \pm 0.037$ & & \\
\hline \multicolumn{5}{|l|}{ Temperature $\left({ }^{\circ} \mathrm{C}\right)$} \\
\hline 4 & 90 & $3.131 \pm 0.064$ & 0.091 & $*$ \\
\hline 14 & 90 & $3.178 \pm 0.064$ & & $*$ \\
\hline 25 & 90 & $3.214 \pm 0.064$ & & $*$ \\
\hline \multicolumn{5}{|l|}{ Time (months) } \\
\hline 0 & 90 & $3.087 \pm 0.064$ & 0.091 & $*$ \\
\hline 2 & 90 & $3.196 \pm 0.064$ & & $*$ \\
\hline 4 & 90 & $3.239 \pm 0.064$ & & $*$ \\
\hline \multicolumn{5}{|l|}{ Product } \\
\hline $\mathrm{WnC}$ & 90 & $2.729 \pm 0.064$ & 0.091 & $*$ \\
\hline $\mathrm{LC}$ & 90 & $3.527 \pm 0.064$ & & $*$ \\
\hline $\mathrm{SC}$ & 90 & $3.267 \pm 0.064$ & & $*$ \\
\hline \multicolumn{5}{|l|}{ Microbe group } \\
\hline TCC aerobe & 54 & $2.996 \pm 0.083$ & 0.117 & * \\
\hline $\mathrm{TFC}$ & 54 & $2.512 \pm 0.083$ & & $*$ \\
\hline TSB aerobe & 54 & $2.389 \pm 0.083$ & & $*$ \\
\hline TCC anaerobe & 54 & $4.226 \pm 0.083$ & & $*$ \\
\hline TSB anaerobe & 54 & $3.748 \pm 0.083$ & & * \\
\hline \multicolumn{5}{|l|}{ Repetition (batch) } \\
\hline 1 & 135 & $3.113 \pm 0.052$ & 0.074 & $*$ \\
\hline 2 & 135 & $3.236 \pm 0.052$ & & $*$ \\
\hline
\end{tabular}

${ }^{a}$ :Least significant difference; ${ }^{b}$ :homogeneity refers to the components of the same effect. Asterisks in various columns indicate significant difference between the two averages. Asterisks in the same column mean no significant difference between the averages. 


\subsection{Evaluation of storability of OSCs}

During the 4-month storage term, temperature as one of the most important factors of microbial propagation was found to be indifferent $(\mathrm{P}=0.1910)$. The water activity was stable during the storage period (Table 2) inhibiting the growth of vegetative forms including moulds, and the germination of bacterial spores. Temperature is considered the main critical factor for controlling bacterial growth, while the effect of $a_{w}$ on growth of moulds is more rate-limiting than temperature (DANTIGNY et al., 2005). In relation to storage time $(\mathrm{P}=0.0033)$, the storability of OSC and of any organic material is time dependent; its magnitude is determined by the effects of environmental factors, which were compliant in our experiment for even long term storage.

In relation to production $(\mathrm{P}=0.0012)$, the surfaces and hard-to-clean areas with clumps of organic materials on the equipments are potential contamination sources, therefore full implementation of industrial cleaning and disinfection tasks reduce the risk of postcontamination, and the magnitude of microbial contamination can be lowered.

\section{Conclusions}

Our results indicate that despite the fact that the OSCs are low-processed materials, they are safe materials for application in the food chain, and provide macronutrients in high ratio. Despite of dilution of microbial contamination in case of food fortification, the spore-forming bacteria cause latent contamination making the high moisture content food products riskier. There is a possible hazard of chemical contamination mostly by mycotoxins or pesticides, etc., not studied here, therefore the monitoring of these substances is necessary. To extend the findings of this study, for the broader confirmation of the results, and for predictive modelling in the field, replicated measurements achieved through long-term storage complemented with measurements for chemical safety are needed.

The authors would like to thank Dr. Olivér Reichart for his help in the statistical analysis.

\section{References}

Cofrades, S., Serrano, A., Ayo, J., Carballo, J. \& Jiménez-Colmenero, F. (2008): Characteristics of meat batters with added native and preheated defatted walnut. Fd Chem., 107, 1506-1552.

Davies, R.H. \& Wray, C. (1997): Distribution of Salmonella contamination in ten animal feedmills. Vet. Microbiol., $51,159-169$.

Dantigny, P., Gullmart, A. \& Bensoussan, M. (2005): Basis of predictive mycology. Int. J. Fd Microbiol., 100, $187-196$.

EÜM (1998): 4/1998. (XI. 11.) EüM rendelet az élelmiszerekben előforduló mikrobiológiai szennyeződések megengedhető mértékéröl (4/1998 EüM order on the acceptable levels of microbiological contamination in foods.) Magyar Közlöny, 1998, 101, 6510-6538.

FVM (2003): 43/2003. (IV. 26.) FVM rendelet a takarmányok előállításáról, forgalomba hozataláról és felhasználásáról szóló 2001. évi CXIX. törvény végrehajtásáról. (Hungarian Agriculture and Rural Development Ministry Regulation No. 43/2003 on implementation of act XCIX of year 2001, on feed production, marketing and use.) Magyar Közlöny, 42, 3123-3203.

Juven, B.J., Cos, N.A., Bailwy, J.S., Thomson, J.E., Charles, O.W. \& Shutze, J.V. (2004): Survival of Salmonella in dry food and feed. J. Fd Prot., 47, 445-448. 
Kolapo, L., Oladimej, G.R., Ifejika, A., Ohenhen, E., Eyitayo, I. R. \& Oywlakin, A.O. (2012): Aflatoxin, nutritive values and microbiological status of stored cakes of some selected Nigerian oil seeds. Glob. J. Sci. Front. Res., 12(5), 12-21.

Lanier, C., Heutte, N., Richard, E., Bouchart, V., Lebailly, P. \& Garon, D. (2009): Mycoflora and mycotoxin production in oilseed cakes during farm storage. J. Agric. Fd Chem., 57, 1640-1645.

Leong, Y.H., Ismail, N., Latif, A.A. \& Ahmad, R. (2010): Aflatoxin occurrence in nuts and commercial nutty products in Malaysia. Fd Control, 21, 334-338.

Marquardt, R.R. (1996): Effects of molds and their toxins on livestock performance: a western Canadian perspective. Anim. Feed Sci. Technol., 58, 77-89.

MSZ EN ISO (2000): Olajmagdarák. Az olajtartalom meghatározása 1. rész: Hexános (vagy petroléteres) extrakciós módszer. (Oilseed meals. Determination of oil content Part 1: Extraction using hexane (or petrol ether) No. MSZ EN ISO 734-1:2000

Mueller, K., Eisner, P., Yoshie-Stark, Y., Nakada, R. \& Kirchioff, E. (2010): Functional properties and chemical composition of fractionated brown and yellow linseed meal (Linum usitatissimum L.). J. Fd Engng, 98, 453460.

Myint, S.M., Johnson, Y.J., Paige, J.C. \& Bautista, D.A. (2007): A cross-sectional study of bacterial contamination in plant-protein feed from feed stores in Northern Virginia and Maryland. Anim. Feed Sci. Technol., 133, $137-148$.

Ogunroni, O. (2007): The suitability of South African flaxseed oilcake for inclusion in bread. Dissertation for the degree Magister Technologiae. Tshwane University of Technology Pretoria, South Africa. pp. 34-60.

Oladimej, G.R. \& Kolapo, A.L. (2008): Evaluation of proximate changes and microbiology of stored defatted residues of some selected Nigerian oil seeds. Afr. J. Agric. Res., 3(2), 126-129.

Perédi, J. \& Balogh, T. (2005): A tökmagolaj és nyersanyagai. (Pumpkin oil and seed.) Olaj, Szappan, Kozmetika, 54(3), 131-135.

Pitt, J.I., Hocking, A.D., Bhudhasamai, K., Miscamble, B.F., Wheeler, K.A. \& Tanboon-Ek, P. (1993): The normal mycoflora of commodities from Thailand. 1. Nuts and oilseeds. Int. J. Fd Microbiol., 20, 211-226.

Popović, L. (2010): Hydrolysis of pumpkin oil cake globulin-cucurbitin by pepsin; Antioxidant and functional properties of resulting hydrolysates. J Biotechn. Suppl., 150, 315.

VANHANEN, L.P. \& SAVAGE, G.P. (2006): The use of peroxide value as a measure of quality for walnut flour stored at five different temperatures using three different types of packaging. Fd Chem., 99, 64-69.

Wallace, P.A., Adu, E.K. \& Rhule, S.W.A. (2010): Optimal storage conditions for cocoa cake with shell, palm kernel cake and copra cake as poultry and livestock feed in Ghana. Livestock Res. Rural Develop., 22, 2 article No 32. http://www.lrrd.org/lrrd22/2/wall22032.htm

Zinedine, A. \& Manes, J. (2009): Occurrence and legislation of mycotoxins in food and feed from Morocco. $F d$ Control, 20, 334-344. 